University of Nebraska - Lincoln

DigitalCommons@University of Nebraska - Lincoln

2006

Estimated Age Structure of Wolves in Northeastern Minnesota

L. David Mech

USGS Northern Prairie Wildlife Research Center, david_mech@usgs.gov

Follow this and additional works at: https://digitalcommons.unl.edu/usgsnpwrc

Part of the Other International and Area Studies Commons

Mech, L. David, "Estimated Age Structure of Wolves in Northeastern Minnesota" (2006). USGS Northern Prairie Wildlife Research Center. 103.

https://digitalcommons.unl.edu/usgsnpwrc/103

This Article is brought to you for free and open access by the US Geological Survey at DigitalCommons@University of Nebraska - Lincoln. It has been accepted for inclusion in USGS Northern Prairie Wildlife Research Center by an authorized administrator of DigitalCommons@University of Nebraska - Lincoln. 


\title{
Estimated Age Structure of Wolves in Northeastern Minnesota
}

\begin{abstract}
L. D. MECH, ${ }^{\mathbf{1}, 2}$ Biological Resources Discipline, United States Geological Survey, Northern Prairie Wildlife Research Center, Jamestown, ND 58401-7317, USA
\end{abstract}

(JOURNAL OF WILDLIFE MANAGEMENT 70(5):1481-1483; 2006)

\section{Key words}

age, Canis lupus, demographics, mortality, population dynamics, survival, turnover, wolf.

Information about population age structures is useful to understand survival rates, longevity, and population turnover. However, little such information is available about wolf (Canis lupus) populations. Mech (1970) estimated age structures of wolf-population age structure from pup:adult ratios applying various demographic assumptions, but no direct information has been published to test his estimate. Mech et al. (1998) aged 94 live wolves darted in Denali National Park and Preserve, Alaska, USA, but the estimates of wolf ages were based on educated guesses because no technique was available for aging live wolves. Since then, Gipson et al. (2000) published criteria for aging live wolves based on tooth wear of known-aged animals. This method allows data to be gathered from populations of live animals, which can facilitate examination of the age structure of populations. My objective was to use this method to estimate the age structure of a population of wolves in the Superior National Forest (SNF) of northeastern Minnesota, USA.

\section{Study Area}

The study area encompassed 2,060 $\mathrm{km}^{2}$ of wilderness immediately east of Ely in the east-central SNF $\left(48^{\circ} \mathrm{N}\right.$, $92^{\circ} \mathrm{W}$ ) of Minnesota and was an arbitrarily defined portion of a much larger region, contiguous to Canada, all of which historically supported wolves without interruption (Stenlund 1955). Topography varied from large stretches of swamps to rocky ridges, with elevation ranging from 325$700 \mathrm{~m}$ above sea level. Winter temperatures $<-35^{\circ} \mathrm{C}$ were not unusual, and snow depths (usually from about mid-Nov through mid-Apr) generally ranged from $50-75 \mathrm{~cm}$ on the level. Temperatures in summer rarely exceeded $35^{\circ} \mathrm{C}$.

Conifers predominated in the forest overstory, with the following species present: jack pine (Pinus banksiana), white pine (P. strobus), red pine (P. resinosa), black spruce (Picea mariana), white spruce ( $P$. glauca), balsam fir (Abies balsamea), northern white cedar (Thuja occidentalis), and tamarack (Larix laricina). However, as a result of extensive cutting and fires, much of the conifer was interspersed with large stands of paper birch (Betula papyrifera) and aspen

\footnotetext{
${ }^{1}$ E-mail: david_mech@usgs.gov

${ }^{2}$ Mailing address: The Raptor Center, University of Minnesota, St. Paul, MN 55108, USA
}

(Populus tremuloides). Detailed descriptions of the forest vegetation were presented by Ohmann and Ream (1969).

Wolves in the study area fed primarily on white-tailed deer (Odocoileus virginianus), moose (Alces alces), and beavers (Castor canadensis; Frenzel 1974). The wolves have been legally protected since 1974, although some have occasionally been killed accidentally or illegally by humans (Mech 1977). The wolf population in the study area has remained relatively stable since about 1975 and since 1990 has numbered about $55 \pm 1.4$ (SE) each year (Mech 2000; L. D. Mech, United States Geological Survey, unpublished data).

\section{Methods}

Five assistants and I live-trapped wolves each year in modified steel foot traps (Mech 1974) set along logging roads, trails, and portages throughout the study area. We sampled animals from about 16 packs throughout the study area from June through November 2000 through 2004. (The movements of wolves between packs within the study area and formation of new packs [Mech 1986, 1987] prevented an exact rendition of the number of packs represented.) We anesthetized, radiocollared, and examined the wolves, and we estimated the age of each wolf in the field by comparing the anesthetized wolfs tooth wear to wear patterns on illustrations of known-age-wolf tooth wear in Gipson et al. (2000). None of us had special training in this aging technique. For most wolves we recorded a single-year estimate, but in 6 cases where a range of years was recorded (e.g., 3-5 yr), I assumed the mid-range to be the actual age. In 13 cases when a range of consecutive years was recorded (e.g., 1-2 yr), I allocated the data to the older age. I based the mean and standard errors (Table 1) on the percentages of each age captured each year of the study.

\section{Results}

We live-trapped 66 individual wolves and estimated their ages (Table 1); we recaptured 6 of them, 3 in the same year as their original capture (Table 2).

The age structure of my sample was heavily skewed to young animals, with only $12 \%$ of the non-pups estimated at $>5$ years of age. Because pups remain near dens and rendezvous sites throughout most of the trapping period, rather than traveling throughout their pack territory, 
Table 1. The estimated ages of wolves live-trapped in the central Superior National Forest of northeastern Minnesota, USA, Jun-Nov 2000-2004, and the proportion of each age class in the total sample and in the non-pup sample. Mean and standard errors are based on percentages of each age captured each year of the study.

\begin{tabular}{ccccc}
\hline & & & \multicolumn{2}{c}{$\%$ non-pups } \\
\cline { 4 - 5 } Age (yr) & No. & $\%$ & $\overline{\boldsymbol{x}}$ & SE \\
\hline & & & & \\
$<1$ & 10 & 14 & & \\
1 & 9 & 13 & 15 & 4 \\
2 & $21^{\mathrm{a}}$ & 30 & 37 & 6 \\
3 & 8 & 12 & 15 & 6 \\
4 & 9 & 13 & 15 & 3 \\
5 & 5 & 7 & 9 & 4 \\
6 & 2 & 3 & 3 & 3 \\
7 & 2 & 3 & 3 & 2 \\
8 & 1 & 1 & 1 & 1 \\
9 & 2 & 3 & 4 & 2 \\
Total & 69 & & & \\
\hline
\end{tabular}

${ }^{a}$ The relatively large size of this cohort probably results from inaccuracy in the aging technique. Many of these animals are probably 1 year old.

trapping is biased against pups. Thus my age data was best viewed as indicating the age structure of the population at least 1 year old.

\section{Discussion}

As with most sampling of wildlife populations, there is no way of knowing how representative my sample was of the study population. Conceivably older wolves were more trapshy, and that could explain my results. To test that possibility, I examined the ages of wolves that were recaptured (Table 2). Although my sample was small, it did indicate that older wolves appeared to be as subject to recapture as younger wolves. This finding supports the probability that my age sample was not biased by differential trappability and that it reasonably represented that of the study population.

In the 13 cases in which age estimates varied by a year, 7 cases involved animals estimated at 1-2 years old. This uncertainty illustrates the difficulty of discriminating between 1 and 2 years of age with the tooth-wear technique and helps explain the apparent disproportionate number of individuals assigned to 2 years in my study (Table 1 ).

The $12 \%$ proportion of wolves $>5$ years old in my study falls between that estimated indirectly for a population in part of Ontario $(20 \%>5 \mathrm{yr}$ old; Mech 1970) and that estimated directly (but without comparison with a knownaged sample) in Denali National Park and Preserve, Alaska $(6 \%>5$ yr old; Mech et al. 1998). It also accords with data from Yellowstone National Park, where wolves monitored from about 9 months old survived an average of only 3.4

\section{Literature Cited}

Frenzel, L. D., Jr. 1974. Occurrence of moose in food of wolves as revealed by scat analyses: a review of North American studies. Naturaliste Canadiene 101:467-479.

Fuller, T. K., L. D. Mech, and J. F. Cochrane. 2003. Wolf population
Table 2. Estimated ages of wolves re-trapped in the central Superior National Forest of northeastern Minnesota, USA, Jun-Nov 2000-2004.

\begin{tabular}{ccc}
\hline & \multicolumn{2}{c}{ Estimated age (yr) } \\
\cline { 2 - 3 } First capture year & First capture & Recapture \\
\hline 2000 & 5 & 9 \\
2002 & 5 & 7 \\
2003 & 1 & 1 \\
2003 & 2 & 2 \\
2003 & 2 & 3 \\
2004 & 4 & 4 \\
\hline
\end{tabular}

years (D. W. Smith, United States National Park Service, personal communication).

Captive wolves can reach 17 years old (E. Klinghammer and P. A. Goodman, North American Wildlife Park Foundation, personal communication in Mech and Boitani 2003), and wild wolves can reach at least 15 (Theberge and Theberge 1998). However, such old animals seem rare (Mech 1988), and my study tends to confirm that conclusion. Besides being killed by humans even when legally protected, wolves kill each other and die of starvation, disease, and injuries from prey (Mech 1977, 1994, Mech et al. 1998, Peterson et al. 1998, Fuller et al. 2003).

It appears from this study, with less certain evidence from others (Mech 1970; Mech et al. 1998; D. W. Smith, personal communication), that most wolves fail to live more than 5 years, which is about when they reach their maximum mass (Mech 2006). Because wolves usually do not begin to breed until 2-4 years old (Kreeger 2003), these facts mean that, at least in my study area, wolves that breed for more than a few years (Mech and Hertel 1983, Mech 1995) are rare.

\section{Management Implications}

My results imply a high natural population turnover in wolves. This fact, in turn, supports findings that human control of wolf populations must compensate for such high natural mortality and that managers seeking to control a wolf population must plan to take a high percentage of the population each year (Fuller et al. 2003).

\section{Acknowledgments}

My study was supported by the Biological Resources Division, United States Geological Survey, and the United States Department of Agriculture North Central Research Station. M. E. Nelson and numerous volunteers livetrapped the study animals and performed the age estimates. D. Boyd, D. Smith, and M. Sovada reviewed the manuscript and offered helpful suggestions for improving it. I also appreciate the Associate Editor and reviewer suggestions.

dynamics. Pages 161-191 in L. D. Mech and L. Boitani, editors. Wolves: behavior, ecology, and conservation. University of Chicago, Chicago, Illinois, USA.

Gipson, P. S., W. B. Ballard, R. M. Nowak, and L. D. Mech. 2000. 
Accuracy and precision of estimating age of gray wolves by tooth wear. Journal of Wildlife Management 64:752-758.

Kreeger, T. J. 2003. The internal wolf: physiology, pathology, and pharmacology. Pages 192-217 in L. D. Mech, and L. Boitani, editors. Wolves: behavior, ecology, and conservation. University of Chicago, Chicago, Illinois, USA.

Mech, L. D. 1970. The wolf: the ecology and behavior of an endangered species. Doubleday, New York, New York, USA.

Mech, L. D. 1974. Current techniques in the study of elusive wilderness carnivores. Transactions of the International Congress of Game Biologists 11:315-322.

Mech, L. D. 1977. Productivity, mortality and population trend of wolves in northeastern Minnesota. Journal of Mammalogy 58:559-574.

Mech, L. D. 1986. Wolf population in the central Superior National Forest, 1967-1985. U.S. Department of Agriculture Forest Service, Research Paper NC-270. North Central Forest Experiment Station, St. Paul, Minnesota, USA.

Mech, L. D. 1987. Age, season, and social aspects of wolf dispersal from a Minnesota pack. Pages 55-74 in B. D. Chepko-Sade, and Z. Halpin, editors. Mammalian dispersal patterns. University of Chicago, Chicago, Illinois, USA.

Mech, L. D. 1988. Longevity in wild wolves. Journal of Mammalogy 69: 197-198.

Mech, L. D. 1994. Buffer zones of territories of gray wolves as regions of intraspecific strife. Journal of Mammalogy 75:199-202.
Mech, L. D. 1995. A ten-year history of the demography and productivity of an arctic wolf pack. Arctic 48:329-332.

Mech, L. D. 2000. The wolves of Minnesota: howl in the heartland. Voyageur, Stillwater, Minnesota, USA.

Mech, L. D. 2006. Age-related body mass and reproductive measurements of gray wolves in Minnesota. Journal of Mammalogy 87:80-84.

Mech, L. D., L. G. Adams, T. J. Meier, J. W. Burch, and B. W. Dale. 1998. The wolves of Denali. University of Minnesota, Minneapolis, USA.

Mech, L. D., and L. Boitani. 2003. Wolves: behavior, ecology, and conservation. University of Chicago, Chicago, Illinois, USA.

Mech, L. D., and H. Hertel. 1983. An eight-year demography of a Minnesota wolf pack. Acta Zoologica Fennica 174:249-250.

Ohmann, L. F., and R. R. Ream. 1969. Vegetation studies in the BWCA-a brief report on plant communities. Naturalist 20:20-29.

Peterson, R. O., N. J. Thomas, J. M. Thurber, J. A. Vucetich, and T. A. Waite. 1998. Population limitation and the wolves of Isle Royale. Journal of Mammalogy 79:828-841.

Stenlund, M. H. 1955. A field study of the timber wolf (Canis lupus) on the Superior National Forest, Minnesota. Minnesota Department of Conservation, Technical Bulletin 4, St. Paul, USA.

Theberge, J. B., and M. T. Theberge. 1998. Wolf country: eleven years tracking the Algonquin wolves. McClelland and Stewart, Toronto, Ontario, Canada.

Associate Editor: Alpizar-Jara. 